\title{
PENINGKATAN KINERJA GURU DALAM PEMBELAJARAN MELALUI SUPERVISI KLINIS DI SMP NEGERI 2 KUBU
}

\author{
Mulyadi Basri \\ Kepala SMP Negeri 2Kubu Kabupaten Kubu Raya \\ Email :mulyadi26062019@gmail.com
}

\begin{abstract}
Teaching feasibility is not sufficient to only measure based on formal education but also to be measured based on how the teacher's performance in learning related to lesson planning and learning implementation.The purpose of this school action research (PTS) is to determine the extent to which principal coaching through clinical supervision can improve teacher performance in learning.In this school action research (PTS) was carried out in 2 cycles, from the results of the actions taken were proven to improve teacher performance in learning, namely by increasing teacher performance in preparing lesson plans from $72.86 \%$ in cycle 1, increasing to $99.2 \%$ in cycle 2. Then the increase in teacher performance in implementing learning from $71.8 \%$ in cycle 1 , increased to $98.6 \%$ in cycle 2. In other words, clinical supervision carried out by researchers as school principals can improve teacher performance in learning.
\end{abstract}

\section{Keywords: Clinical Supervision, Learning, Teacher Performance}

\section{PENDAHULUAN}

Pendidikan merupakan proses memanusiakan manusia agar mampu mengaktualisasikan diri dalam kehidupan, dimana pendidikan yang baik adalah pendidikan yang tidak hanya mempersiapkan para siswanya untuk suatu profesi atau jabatan, tetapi untuk menyelesaikan masalahmasalah yang dihadapinya dalam kehidupan sehari-hari. Idealnya pendidikan tidak hanya mendorong siswa untuk mengembangkan bakat yang disesuaikan dengan ilmu yang di peroleh di sekolah, akan tetapi pendidikan juga bertujuan untuk meningkatkan kualitas manusia yaitu manusia yang beriman dan bertakwa kepada Tuhan Yang Maha Esa, berbudi pekerti luhur, berkepribadian, mandiri, maju, tangguh, cerdas, kreatif, terampil, berdisiplin, beretos kerja, professional, bertanggung jawab, produktif, dan sehat jasmani-rohani.

Guru adalah seseorang profesional yang mendidik serta membimbing siswa di lingkungan sekolah, guru dituntut untuk memiliki kompetensi selain mengajar juga melakukan penelitian. Guru adalah pendidik profesional dengan tugas utama mendidik, mengajar, mengarahkan, melatih, menilai dan mengevaluasi siswa pada pendidikan anak usia dini jalur pendidikan formal, pendidikan dasar, dan pendidikan menengah (Peraturan Pemerintah nomor 19 tahun 2005 Pasal 1.1). Berdasarkan Standar Pendidik dalam Peraturan Pemerintah tersebut disebutkan bahwa "Pendidik harus memiliki kualifikasi akademik dan kompetensi sebagai agen pembelajaran, sehat jasmani dan rohani serta memilki kemampuan untuk mewujudkan tujuan pendidikan nasional".

Lebih lanjut Brown dalam Sardiman (2000: 142) menjelaskan tugas dan peranan guru, antara lain: menguasai dan mengembangkan materi pelajaran, merencanakan dan mempersiapkan pela-jaran sehari-hari, mengontrol dan mengevaluasi kegiatan belajar siswa.Undangundang tentang Guru dan Dosen Nomor 14 Tahun 2005 dan Peraturan Pemerintah Nomor 19 Tahun 2005 tentang Standar Nasional Pendidikan menyatakan bahwa kompetensi guru meliputi kompetensi kepribadian, pedagogik, profesional, dan sosial. Adapun yang dimaksud dengan keempat jenis kompetensi guru adalah: (1) Kompetensi
Kepribadian merupakan kemampuan personal yang mencerminkan kepribadian yang mantap, stabil, dewasa, arif, dan berwibawa, menjadi teladan bagi siswa, dan berakhlak mulia; (2) Kompetensi Pedagogik, merupakan pemahaman terhadap siswa, perancangan dan pelaksanaan pembelajaran, evaluasi hasil belajar, dan pengembangan siswa untuk mengaktualisasikan berbagai potensi yang dimilikinya; (3) Kompetensi Profesional merupakan penguasaan materi pembelajaran secara luas dan mendalam, yang mencakup penguasaan materi kurikulum mata pelajaran di sekolah dan substansi keilmuan yang menaungi materinya, serta penguasaan terhadap stuktur dan metodologi keilmuannya; (4) Kompetensi Sosial merupakan kemampuan guru untuk berkomunikasi dan bergaul secara efektif dengan siswa, sesama pendidik, tenaga kependidikan, orangtua/wali siswa, dan masyarakat sekitar.

Istilah kinerja dapat diterjemahkan dalam kata "perfomance" atau unjuk kerja, artinya kemampuan yang ditampilkan seseorang terhadap pekerjaannya pada tempat ia bekerja. Kinerja merupakan suatu kinerja yang esensial terhadap keberhasilan suatu pekerjaan. Karena itu suatu kinerja yang efektif bagi setiap individu perli diciptakan sehingga tujuan lembaga dapat tercapai secara optimal.

Menurut Fattah (1996:45) kinerja diartikan sebagai ungkapan kemajuan yang didasari oleh pengetahuan, sikap, keterampilan dan otivasi dalam menghasilkan suatu pekerjaan. Dengan demikian dapat disimpulkan bahwa kinerja adalah hasil kerja seseorang yang mencerminkan prestasi kerja sebagai ungkapan pengetahuan, sikpa dan keterampilan.

Dari pendapat tersebut di atas, maka yang dimaksud dengan kinerja guru dalam penelitian ini ialah: (1) penguasaan bahan ajar, (2) pemahaman karakteristik, (3) penguasaan pengelolaan kelas, (4) penguasaan metode dan strategi pembelajaran, (5) penguasaan evaluasi pembelajaran, dan (6) kepribadian.dan (7) disiplin guru dalam melaksanakaan.

Sedangkan pengertian guru dapat dijelaskan bahwa kata guru dalam bahasa Arab disebut Mu'allim dan dalam bahasa Inggris guru disebut dengan teacher yang memiliki arti "A person whose 
occupation is teaching others", yaitu seseorang yang pekerjaannya mengajar orang lain (Muhibbin Syah, 2003; 222).

Menurut Undang-Undang Nomor 14 tahun 2004 tentang Guru dan Dosen, yang disebut guru adalah pendidik profesional dengan tugas utama mendidik, mengajar, membimbing, mengarahkan, melatih, menilai, dan mengevaluasi siswa pada pendidikan anak usia dini jalur pendidikan formal, pendidikan dasar, dan pendidikan menengah. Sedangkan pembelajaran merupakan wujud dari kinerja guru, maka segala kegiatan pembelajaran yang dilakukan guru harus menyatu, menjiwai, dan menghayati tugas-tugas yang relevan dengan tingkat kebutuhan, minat, bakat dan tingkat kemampuan siswa serta kemampuan guru dalam mengorganisasi materi pembelajaran dengan penggunaan ragam teknologi pembelajaran yang memadai. Pengertian pembelajaran menurut Undang-undang Sistem Pendidikan Nasional tahun 2003 adalah suatu proses interaksi siswa dengan pendidik dan sumber belajar pada suatu lingkungan belajar. Maka Proses pembelajaran merupakan suatu proses yang mengandung serangkaian perbuatan guru dan siswa atas hubungan timbal balik yang berlangsung dalam situasi edukatif untuk mencapai tujuan tertentu.

Supervisi menjadi bagian dari manajemen Pendidikan nasional karena terdapatnya bab khusus mengenai pengawasan dalam Undang-Undang Sistem Pendidikan Nasional Nomor 20 Tahun 2003 yang diatur lebih lanjut dengan peraturan pemerintah. Oleh karena itu supervisi Pendidikan mempunyai kedudukan strategis dan penting dalam manajemen kependidikan, maka sudah menjadi keharusan bagi pemerintah untuk berupaya secara terus menerus menjadikan para pelaksana supervisi pendidikan sebagai tenaga yang profesional.

Supervisi merupakan bagian keempat dari empat kegiatan proses pembelajaran yang dilaksanakan oleh tim supervisor baik oleh kepala sekolah dan/atau pengawas. Keempat proses pembelajaran itu antara lain; diawali dengan perencanaan, kemudian pelaksanaan, diteruskan dengan penilaian, dan yang keempat pengawasan.

Dalam penelitian ini peneliti mencoba untuk mengkaji dan menggali melalui supervisi klinis yang berkaitan dengan kinerja guru dalam pembelajaran. Masalah ini disebabkan oleh; (1). Adanya kecenderungan melemahnya kinerja guru yaitu terjadinya guru yang membolos mengajar, guru yang masuk ke kelas yang tidak tepat waktu, guru mengajar tidak mempunyai persiapan mengajar, (2) adanya pelaksanaan supervisi yang dilakukan oleh kepala sekolah belum dilaksanakan dengan maksimal kepada guru. Beberapa guru belum maksimal mempersiapkan perangkat pembelajarannya baik sebelum atau saat pelaksanaan pembelajaran, (3) adanya penurunan kinerja guru merupakan salah satu penyebab menurunnya nilai ulangan siswa di SMP Negeri 2 Kubu Kabupaten Kubu Raya.

Supervisi klinis merupakan pembinaan profesional yang dilakukan secara sistematis kepada guru sesuai kebutuhan guru yang bersangkutan dengan tujuan untuk membina keterampilan mengajarnya. Pembinaan itu dilakukan dengan cara yang memungkinkan guru menemukan sendiri caracara untuk memperbaiki kekurangannya sendiri (dalam suatu pengakuan yang jujur dan tulus).
Lebih lanjut dikemukakan oleh Hartoyo (2006:45) Supervisi klinis adalah bentuk supervisi yang difokuskan pada peningkatan mengajar dengan melalui suatu siklus yang sistematik dalam perencanaan, pengamatan serta analisis yang intensif dan cermat tentang penampilan yang mengajar nyata, serta bertujuan mengadakan perubahan dengan cara yang rasional. K.A. Acheson \& M.D. Gall (1997:112) mengemukakan bahwa supervisi klinis adalah proses membantu guru memperkecil ketidaksesuaian atau kesenjangan tingkah laku mengajar yang nyata dengan tingkah laku yang ideal.

Dari kedua pendapat tersebut di atas dapat disimpulkan bahwa supervisi klinis adalah suatu proses kepemimpinan dalam pendidikan yang bertujuan membantu pengembangan profesional guru khususnya dalam penampilan mengajar berdasarkan observasi dan analisis data secara teliti dan objektif sebagai pegangan untuk perubahan tingkah laku mengajar tersebut.Supervisi klinis termasuk bagian dari supervisi pengajaran. Dikatakan supervisi klinis karena prosedur pelaksanaannya lebih ditekankan kepada mencari sebab-sebab atau kelemahan yang terjadi dalam proses belajar mengajar, dan kemudian secara langsung pula diusahakan bagaimana cara memperbaiki kelemahan atau kekurangan tersebut. Adapun ciri-ciri atau karakteristik dari supervisi klinis yang membedakan dengan supervisi lainnya, yaitu sebagai berikut:a) Pada dasarnya kepala sekolah dan guru sederajat dan saling membantu dalam meningkatkan kemampuan dan sikap keprofesionalannya.b)Fokus supervisi klinis adalah pada perbaikan cara mengajar bukan mengubah kepribadian guru.c)Balikan supervisi klinis didasarkan atas bukti pengamatan dan bukan atas keputusan penilaian yang tidak di dukung oleh bukti nyata.d)Bersifat konstruktif dan memberi penguatan pada pola-pola dan tingkah laku yang berhasil daripada mencela dan "menghukum" pola-pola tingkah laku yang belum berhasil.e)Tahapan supervisi klinis merupakan kontinuitas dan dibangun atas dasar pengalaman masa lampau.f)Supervisi klinis merupakan suatu proses memberi dan menerima yang dinamis dimana kepala sekolah dan guru merupakan teman sejawat di dalam mencari pengertian bersama dalam proses pendidikan. g)Tiap guru mempunyai kebebasan dan tanggung jawab untuk mengemukakan pokokpokok persoalan, menganalisis cara mengajarnya sendiri dan mengembangkan gaya mengajarnya.h)Kepala sekolah mempunyai kebebasan maupun tanggung jawab untuk menganalisis dan mengevaluasi cara melakukan supervisi sebagaimana cara menganalisis cara mengajar guru. i) Guru mempunyai prakarsa dan tanggung jawab dalam meningkatkan kompetensi pedagogik yaitu kemampuan mengelola pembelajaran. j) Kepala sekolah dan guru bersifat terbuka dalam mengemukakan pendapat.

Sebagaimana lazimnya pelaksanaan supervis pengajaran tidak terlepas dari prosedur dan tahapan dalam pelaksanaannya. Demikian pula kegiatan supervisi klinis, dilaksanakan dengan tahapan yang sistematis. Pada dasarnya para ahli mempunyai prinsip yang sama, bahwa supervisi klinis berlangsung dalam suatu proses yang berbentuk siklus dengan tiga tahap yaitu (1) pertemuan awal, 
(2) tahap observasi kelas, (3) tahap pertemuan balikan/evaluasi.

Pada tahap pertemuan awal merupakan pembuatan kerangka kerja, karena itu perlu diciptakan suasana akrab dan terbuka antara kepala sekolah dengan guru, sehingga guru merasa percaya diri dan memahami tujuan diadakan pendekatan klinis.

Pada tahap observasi kelas, guru melakukan kegiatan pembelajaran sesuai pedoman dan prosedur yang telah disepakati pada saat pertemuan awal. Selanjutnya kepala sekolah melakukan observasi berdasarkan instrument yang telah dibuat dan disepakati dengan guru.

Pertemuan setelah observasi berlangsung, kepala sekolah menggunakan informasi yang dikumpulkan untuk membantu guru dalam menganalisis pelajaran. Pertemuan setelah observasi lebih memfokuskan permasalahan yang sebelumnya sudah disetujui bersama dan tidak menyimpang dari kesepakatan pertemuan awal. Dengan kata lain, pembahasan ataupun diskusi berlangsung dengan suasana keterbukaan dan saling menghargai.

Pada tahap akhir dari siklus supervisi klinis adalah analisis pasca pertemuan (post observation). Kepala sekolah mengevaluasi hal-hal yang telah terjadi selama observasi dan seluruh siklus proses supervisi dengan tujuan untuk meningkatkan performansi guru. Pertemuan akhir merupakan diskusi umpan balik antara kepala sekolah dan guru.

Suasana pertemuan sama dengan suasana pertemuan awal yaitu suasana akrab penuh persahabatan, bebas dari prasangka, dan tidak bersifat mengadili. Kepala sekolah memaparkan data secara objektif sehingga guru dapat mengetahui kekurangan dan kelebihan selama proses pembelajaran berlangsung. Yang menjadi dasar dari balikan terhadap guru adalah kesepakatan tentang item-item observasi yang telah dibuat, disadari tingkat prestasi yang dicapai.

Pada prinsipnya setiap guru harus disupervisi secara periodik dalam melaksanakan pembelajaran. Jika jumlah guru cukup banyak, kepala sekolah dapat meminta bantuan wakil kepala sekolah atau guru senior untuk membantu melaksanakan supervisi. Dengan demikian, jika bidang studi guru terlalu jauh, dan kepala sekolah merasa sulit memahami, kepala sekolah dapat meminta bantuan kepada guru senior yang memiliki latar belakang bidang studi yang sama dengan guru yang ingin disupervisi.Hipotesis tindakan dalam penelitian ini adalah "Kinerja guru dalam pembelajaran akan meningkat jika supervisi klinis dilaksanakan dengan sistematis dan proaktif".

\section{METODE PENELITIAN}

Penelitian ini dilaksanakan di SMP Negeri 2 Kubu Kabupaten Kubu Raya pada tahun pelajaran 2019-2020. Penelitian tindakan sekolah ini dilakukan pada guru melalui Supervisi Klinis untuk meningkatkan kinerja guru dalam pembelajaran di SMP Negeri 2 Kubu Kabupaten Kubu Raya.

Waktu penelitian adalah mulai tanggal 2 September sampai dengan 25 Nopember 2019. Selama penelitian tersebut peneliti mengumpulkan data awal, menyusun program supervisi, pelaksanaan supervisi, analisis, dan tindak lanjut.Subyek dalam penelitian ini adalah guru SMP Negeri 2 Kubu Kabupaten Kubu Raya yang merupakan tempat peneliti bertugas menjadi kepala sekolah tahun pelajaran 2019-2020.

Karena penelitian ini merupakan penelitian tindakan maka pelaksanakan ini dilaksanakan secara siklus. Pelaksanaannya dilakukan selama dua siklus. Siklus-siklus tersebut merupakan rangkaian yang saling berkelanjutan, maksudnya siklus kedua merupakan kelanjutan dari siklus pertama. Setiap siklusnya selalu ada persiapan tindakan, pelaksanaan tindakan, pemantauan dan evaluasi, dan refleksi.

\section{HASIL DAN PEMBAHASAN}

\section{Hasil Siklus 1}

Berdasarkan pemantauan selama persiapan, pelaksanaan, dan tindak lanjut penelitian tindakan sekolah ini diperoleh berbagai data yaitu dari guru yang sedang melaksanakan proses belajar mengajar dan siswa yang sedang belajar. Gambaran yang merupakan hasil penelitian sebagai berikut:

Tabel 1. Rekapitulasi Hasil Penilaian Perencanaan Pembelajaran Siklus 1

\begin{tabular}{|c|c|c|c|c|}
\hline No & Indikator & $\begin{array}{l}\text { Jumlah } \\
\text { Guru }\end{array}$ & $\begin{array}{c}\text { JML Guru } \\
\text { Berhasil } \\
\text { (Skor } \geq 75\end{array}$ & \% Keberhasilan \\
\hline 1 & Identitas Sekolah yaitu nama satuan pendidikan & 21 & 21 & 100 \\
\hline 2 & Identitas Mata Pelajaran atau Tema/Subtema; & 21 & 21 & 100 \\
\hline 3 & Kelas/Semester; & 21 & 21 & 100 \\
\hline 4 & Materi Pokok; & 21 & 21 & 100 \\
\hline 5 & Alokasi Waktu & 21 & 21 & 100 \\
\hline 6 & $\begin{array}{l}\text { Tujuan Pembelajaran yang dirumuskan berdasarkan } \\
\text { KD }\end{array}$ & 21 & 10 & 47,6 \\
\hline 7 & $\begin{array}{l}\text { Kompetensi Dasar dan Indikator Pencapaian } \\
\text { Kompetensi }\end{array}$ & 21 & 10 & 47,6 \\
\hline 8 & Materi Pembelajaran & 21 & 14 & 66,6 \\
\hline 9 & Metode Pembelajaran & 21 & 10 & 47,6 \\
\hline 10 & Media Pembelajaran & 21 & 10 & 47,6 \\
\hline 11 & Sumber Belajar & 21 & 16 & 76,1 \\
\hline 12 & Langkah-Langkah Pembelajaran & 21 & 10 & 47,6 \\
\hline \multirow[t]{2}{*}{13} & Penilaian Hasil Pembelajaran & 21 & 14 & 66,6 \\
\hline & Rata - Rata Keberhasilan & & & $72,86 \%$ \\
\hline
\end{tabular}


Tabel 2. Rekapitulasi Hasil Penilaian Melaksanakan Pembelajaran Tindakan

\begin{tabular}{llccc}
\hline No & \multicolumn{1}{c}{ Indikator } & $\begin{array}{c}\text { Jumlah } \\
\text { Guru }\end{array}$ & $\begin{array}{c}\text { JML Guru } \\
\text { Berhasil } \\
\text { (Skor } \geq \mathbf{7 5}\end{array}$ & \% Keberhasilan \\
\hline 1 & Membuka pelajaran dengan metode yang tepat & 21 & 15 & 71,4 \\
\hline 2 & Menyajikan materi pelajaran secara sistematis & 21 & 16 & 76,1 \\
\hline 3 & $\begin{array}{l}\text { Menerapkan metode dan prosedur pembelajaran } \\
\text { yang telah ditentukan }\end{array}$ & 21 & 14 & 66,6 \\
\hline 4 & Mengatur kegiatan siswa di kelas & 21 & 17 & 81 \\
\hline 5 & Menentukan media pembelajaran & 21 & 15 & 71,4 \\
\hline 6 & Menggunakan sumber belajar & 21 & 18 & 66,4 \\
\hline 7 & $\begin{array}{l}\text { Memotivasi siswa dengan berbagai cara yang } \\
\text { positif }\end{array}$ & 21 & 16 & 85,7 \\
\hline 8 & $\begin{array}{l}\text { Melakukan interaksi dengan siswa menggunakan } \\
\text { bahasa yang komunikatif }\end{array}$ & 21 & 15 & 71,4 \\
\hline 9 & Memberikan pertanyaan dan umpan balik & 21 & 14 & 66,6 \\
\hline 10 & Menyimpulkan pembelajaran & 21 & 14 & 66,6 \\
\hline 11 & Menggunakan waktu secara efektif & 21 & 14 & 66,6 \\
\hline & Rata - Rata Keberhasilan & & \\
\hline
\end{tabular}

\section{Hasil Siklus 2}

Mengacu pada perencanaan supervisi di siklus 1, peneliti berdiskusi dengan guru untuk merumuskan kembali tujuan yang akan dicapai dalam pembelajaran. Tujuan itu bersumber pada KI
/ KD atau pokok bahasan dan indikator kompetensi guru yang telah dirumuskan. Hasil pembuatan perangkat tersebut dipahami bersama sebelum diberikan pada siswa.Hasil siklus kedua dapat dilihat pada tabel berikut ini:

Tabel 3. Rekapitulasi Hasil Penilaian Perencanaan Pembelajaran Siklus 2

\begin{tabular}{llccc}
\hline No. Indikator & & $\begin{array}{c}\text { Jumlah } \\
\text { Guru }\end{array}$ & $\begin{array}{c}\text { JML Guru } \\
\text { Berhasil } \\
\text { (Skor } \geq \mathbf{7 5}\end{array}$ & \% Keberhasilan \\
\hline 1 & Identitas Sekolah yaitu nama satuan pendidikan & 21 & 21 & 100 \\
\hline 2 & Identitas Mata Pelajaran atau Tema/Subtema; & 21 & 21 & 100 \\
\hline 3 & Kelas/Semester; & 21 & 21 & 100 \\
\hline 4 & Materi Pokok; & 21 & 21 & 100 \\
\hline 5 & Alokasi Waktu & 21 & 21 & 100 \\
\hline 6 & Tujuan Pembelajaran yang dirumuskan berdasarkan & 21 & 21 & 100 \\
& KD & & & 100 \\
\hline 7 & Kompetensi Dasar dan Indikator Pencapaian & 21 & 21 & 100 \\
& Kompetensi & & & 95,2 \\
\hline 8 & Materi Pembelajaran & 21 & 21 & 95,2 \\
\hline 9 & Metode Pembelajaran & 21 & 20 & 100 \\
\hline 10 & Media Pembelajaran & 21 & 20 & 100 \\
\hline 11 & Sumber Belajar & 21 & 21 & 100 \\
\hline 12 & Langkah-Langkah Pembelajaran & 21 & 21 & $\mathbf{9 9 , 2} \%$ \\
\hline 13 & Penilaian Hasil Pembelajaran & 21 & 21 & \\
\hline & Rata - Rata Keberhasilan & & & \\
\hline
\end{tabular}

Tabel 4. Rekapitulasi Hasil Melaksanakan Pembelajaran Tindakan Siklus 2

\begin{tabular}{|c|c|c|c|c|}
\hline No & Indikator & $\begin{array}{c}\text { Jumlah } \\
\text { Guru }\end{array}$ & $\begin{array}{c}\text { JML Guru } \\
\text { Berhasil } \\
\text { (Skor } \geq 75\end{array}$ & \% Keberhasilan \\
\hline 1 & Membuka pelajaran dengan metode yang tepat & 21 & 20 & 95,2 \\
\hline 2 & Menyajikan materi pelajaran secara sistematis & 21 & 21 & 100 \\
\hline 3 & $\begin{array}{l}\text { Menerapkan metode dan prosedur pembelajaran } \\
\text { yang telah ditentukan }\end{array}$ & 21 & 20 & 95,2 \\
\hline 4 & Mengatur kegiatan siswa di kelas & 21 & 21 & 100 \\
\hline 5 & Menentukan media pembelajaran & 21 & 20 & 95,2 \\
\hline 6 & Menggunakan sumber belajar & 21 & 21 & 100 \\
\hline 7 & $\begin{array}{l}\text { Memotivasi siswa dengan berbagai cara yang } \\
\text { positif }\end{array}$ & 21 & 21 & 100 \\
\hline 8 & $\begin{array}{l}\text { Melakukan interaksi dengan siswa menggunakan } \\
\text { bahasa yang komunikatif }\end{array}$ & 21 & 21 & 100 \\
\hline 9 & Memberikan pertanyaan dan umpan balik & 21 & 21 & 100 \\
\hline 10 & Menyimpulkan pembelajaran & 21 & 21 & 100 \\
\hline 11 & Menggunakan waktu secara efektif & 21 & 21 & 100 \\
\hline & Rata - Rata Keberhasilan & & & $98,6 \%$ \\
\hline
\end{tabular}




\section{Pembahasan}

Adapun pembahasan hasil penelitian ini adalah bahwa kinerja guru meningkat dalam pembelajaran. Hal ini terjadi karena adanya kerja sama antara guru yang satu dengan lainnya serta diberi pengarahan oleh peneliti. Langkah-langkah yang dapat meningkatkan kinerja guru dalam pembelajaran adalah: (1) Peneliti memberikan format supervisi dan jadwal supervisi pada awal tahun pelajaran atau awal semester. Pelaksanaan supervisi tidak hanya dilakukan sekali, (2) Peneliti selalu menanyakan perkembangan pembuatan perangkat pembelajaran (mengingatkan pentingnya perangkat pembelajaran).

Di dalam penelitian tindakan sekolah ini ternyata dari 21 guru, hampir semuanya mampu melaksanakan pembelajaran dengan baik. Hal ini terbukti dari hasil supervisi klinis yang dilakukan oleh peneliti. Langkah-langkah yang dilakukan untuk meningkatkan pelaksanaan pembelajaran berdasarkan penelitian tindakan sekolah ini adalah: (1) Peneliti yang mengamati guru mengajar tidak sebagai penilai tetapi sebagai rekan bekerja yang siap membantu guru tersebut, (2) Selama pelaksaaan supervisi di kelas guru tidak menganggap Peneliti sebagai penilai karena sebelum pelaksanaan supervisi guru dan Peneliti telah berdiskusi permasalahan-permasalahan yang ada dalam pembelajaran tersebut, (3) Peneliti mencatat semua peristiwa yang terjadi di dalam pembelajaran baik yang positif maupun yang negatif, (4) Peneliti selalu memberi contoh pembelajaran yang berorientasi pada Modern Learning. (5) Jika ada guru yang pembelajarannya kurang jelas tujuan, penyajian, umpan balik, Peneliti memberikan contoh bagaimana menjelaskan tujuan, menyajikan, memberi umpan balik kepada guru tersebut.

Berdasarkan penjelasan diatas, kinerja guru dalam pembelajaran akan meningkat jika supervisi klinis dilaksanakan dengan sistematis dan proaktif. Dengan demikian maka hipotesis yang diajukan dapat diterima.

\section{SIMPULAN DAN SARAN Simpulan}

Berdasarkan hasil penelitian, ada beberapa simpulan yang dikemukakan dalam penelitian tindakan ini: 1.Peningkatan kinerja guru dalam menyusun rencana pembelajaran pada siklus 1 adalah $72,86 \%$ meningkat menjadi $99,2 \%$ pada siklus 2.2.Peningkatan kinerja guru dalam melaksanakan pembelajaran adalah $71,8 \%$ pada siklus 1 dan meningkat menjadi $98,6 \%$ pada siklus 2.3.Pelaksanaan supervisi klinis dapat meningkatkan kinerja guru dalam pembelajaran apabila terjadi peningkatan kemampuan guru dalam menyusun rencana pembelajaran dan dalam melaksanakan pembelajaran yang benar dan sesuai dengan kurikulum yang berlaku yaitu kurikulum 2013.

\section{Saran}

Dari hasil penelitian yang diperoleh dari uraian sebelumnya agar kinerja guru dalam pembelajaran dapat meningkat, lebih efektif dan lebih memberikan hasil yang optimal bagi kegiatan pembelajaran sekolah, maka disampaikan saran sebagai berikut:1.Untuk pembinaan melalui Supervisi klinis memerlukan persiapan yang cukup matang, sehingga kepala sekolah harus mampu menentukan atau memilih model pembinaan yang diberikan sehingga diperoleh peningkatan kinerja guru dalam pembelajaran yang optimal.2. Dalam rangka meningkatkan kinerja guru dalam pembelajaran, kepala sekolah hendaknya lebih sering melatih guru dengan kegiatan penemuan, walau dalam taraf yang sederhana, di mana guru nantinya dapat menemukan pengetahuan baru, memperoleh konsep dan keterampilan, sehingga guru lebih berhasil atau mampu memecahkan masalah-masalah yang dihadapinya.

\section{DAFTAR RUJUKAN}

Acheson, K. A., \& Gall, M. D. 1997. Techniques in the clinical supervision of the teachers: Preservice and inservice applications (4th ed.). White Palins, NY: Longman.

A.M, Sardiman. 2000. Interaksi \& Motivasi Belajar Mengajar. Jakarta: Rajawali. Pers.

Glickman, C.D. (1981). Developmental Supervision. Washington : Association for. Supervision and Curriculum Development.

Fattah, Nanang,. 1996Landasan Manajemen Pendidikan. Bandung: PT Remaja. Rosdakarya.

Hartoyo. 2006. Supervisi Pendidikan; Mewujudkan Sekolah Efektif Dalam. Kerangka Manajemen Berbasis Sekolah. Semarang: Pelita Insani.

Kemmis \& Mc. Taggart. 2010. The Action Research Planner. Geelong: Deaken Univercity Press.

Moeheriono. (2009). Pengukuran Kinerja Berbasis Kompetensi. Bogor: Ghalia

Muhibbin Syah. 2003. Psikologi Pendidikan dengan Pendekatan Baru. Bandung: Remaja Rosdakarya

Mulyasa, E, 2004. Kurikulum Berbasis Kompetensi Konsep, Karakteristik, Implementasi, dan Inovasi. Bandung : PT Remaja Rosdakarya.

Undang-Undang Nomor 14 Tahun 2005,.Tentang Guru dan Dosen, Jakarta: Depdiknas.

Undang-Undang Nomor 20 Tahun 2003 Tentang SistemPendidikan Nasional. Jakarta

Peraturan Menteri Pendidikan dan Kebudayaan Nomor 23 Tahun 2016 Tentang Standar Penilaian Pendidikan. Kemendikbud

Peraturan Menteri Pendidikan dan Kebudayaan Nomor 53 Tahun 2015 Tentang Penilaian Hasil Belajar .Kemendikbud. Poerwadarminta, W.J.S. 2005. Kamus Umum Bahasa Indonesia. Edisi Ketiga. Jakarta: Balai Pustaka.

Prawirosentono, Suyadi. 1999. Kebijakan Kinerja Karyawan. Yogyakarta: BPFE. Peraturan Pemerintah Nomor 19 Tahun. 2005, tentang Standar Nasional Pendidikan, Jakarta: Depdiknas.

Wina Sanjaya. 2005. Pembelajaran dalam Implementasi Kurikulum Berbasis Kompetensi.Jakarta: Kencana Media Group 